\title{
Larva migrans: A CASE REPORT AND REVIEW
}

Paulo Eduardo Neves Ferreira VELHO(1), Andreia Vasconcellos FARIA(1), Maria Letícia CINTRA(2), Elemir Macedo de SOUZA(1) \& Aparecida Machado de MORAES(1)

\begin{abstract}
SUMMARY
A case of massive Ancylostoma sp. larval infestation is presented in a patient who had received systemic corticosteroid therapy. What attracts attention in this case is the exuberance and rarity of clinical manifestation. Based on the pertinent literature, we discuss the mechanisms of parasital infection, the natural history of the disease and its treatment.
\end{abstract}

KEYWORDS: Creeping eruption; Larva migrans; Skin.

\section{INTRODUCTION}

Creeping eruption, as it is also called, was described by Lee in 1874 . Subsequently, the term larva migrans was linked to the Ancylostoma sp. larva by White and Dove in $1928^{9,10}$. It is one of the most frequent cutaneous infestations in warm countries (Latin America, the Caribbean, Africa, Southeast Asia and South-Western United States) ${ }^{4}$. It is also the most common travel-associated dermatoses in tourists who travel to tropical areas ${ }^{2}$.

With a predominantly clinical diagnosis in the most prevalent areas, it is usually under-diagnosed in temperate countries. This fact leads to a delay in starting treatment and, not infrequently, to the exacerbation of the clinical manifestation, often aided by the mistaken prescription of corticosteroid.

\section{CASE REPORT}

A 44-year-old Caucasian man, truck driver, came to the State University of Campinas (Unicamp), Dermatology Clinic stating that three months before he had been victim of assault and battery, which left him unconscious on the ground for several hours. He had been hospitalized in coma and given intravenous therapy with corticoid for cerebral edema. Upon regaining consciousness days later, he noted erythematous, edematous and intensely pruritic lesions on the left frontal region and on the left parietotemporal, preauricular, orbicular and malar ones (Figs. 1 and 2). At the same time, similar lesions appeared in the deltoidal region (Fig. 3) and arm, and other sparse lesions on the abdomen and upper thigh, all on the left side.

He also reported having been subsequently seen by several doctors who prescribed corticoid of diverse strengths.
When examined, he had confluent, eczematoid, edemato-infiltrative, cerebriform and peau d'orange-looking lesions on the cephalic segment in the aforementioned regions. There were small papules of up to $5 \mathrm{~mm}$, palpable further beyond. On the left arm and deltoidal region, there were erythematous infiltrated papules of 5 to $10 \mathrm{~mm}$, and other erythematous serpiginous ones. There were also isolated lesions on the abdomen and thigh. Most of these were follicular.

The skin biopsy performed on the fronto-parietal and deltoidal regions showed dermoepidermitis, both subacute and chronic, superficial and deep, with multiple foci of eosinophilic folliculites (Fig. 5). Focally, in a superficial vein, a circular structure could be seen, with an external lining of keratin, suggesting Ancylostoma sp. larva (Fig. 6).

The patient was treated with albendazole, $400 \mathrm{mg}$ per day for three days. Due to the severity of the lesions, a second cycle was prescribed after 21 days. At the end of the treatment, there was a complete regression of the manifestations, with recovery of hair growth of the alopecic areas associated with the lesions (Fig. 4). After 24 months, the patient stated that he had not had any more cutaneous lesions.

\section{REVIEW OF THE LITERATURE}

The causal agents of larva migrans are the A. braziliense and the $A$. caninum, whose eggs are found in dog and cat faeces. Some authors also consider the Uncinaria stenocephala, the Gnathostoma spinigerum and the Bunostomun phlebotomum as causal agents'. Others, however, indicate subtle differences in the appearance of the lesions, which leads them to characterize them as distinct dermatoses ${ }^{4,12}$. Man is an accidental host to these hookworms. Cats and dogs are definitive hosts ${ }^{4}$.

The larvae in the soil, in their third stage, penetrate the organism

(1) Department of Internal Medicine, Faculdade de Ciências Médicas, Universidade Estadual de Campinas, FCM/Unicamp, Campinas, SP, Brazil.

(2) Department of Pathological Anatomy, FCM/Unicamp, Campinas, SP, Brazil.

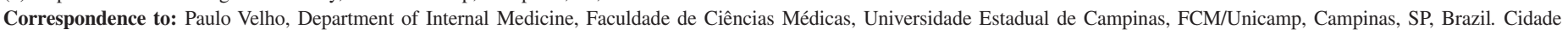
Universitária Zeferino Vaz, s/n, 13081-970 Campinas, SP, Brazil. Fone/Fax: 55-19-3289-4107. E-mail: pvelho@ fcm.unicamp.br 


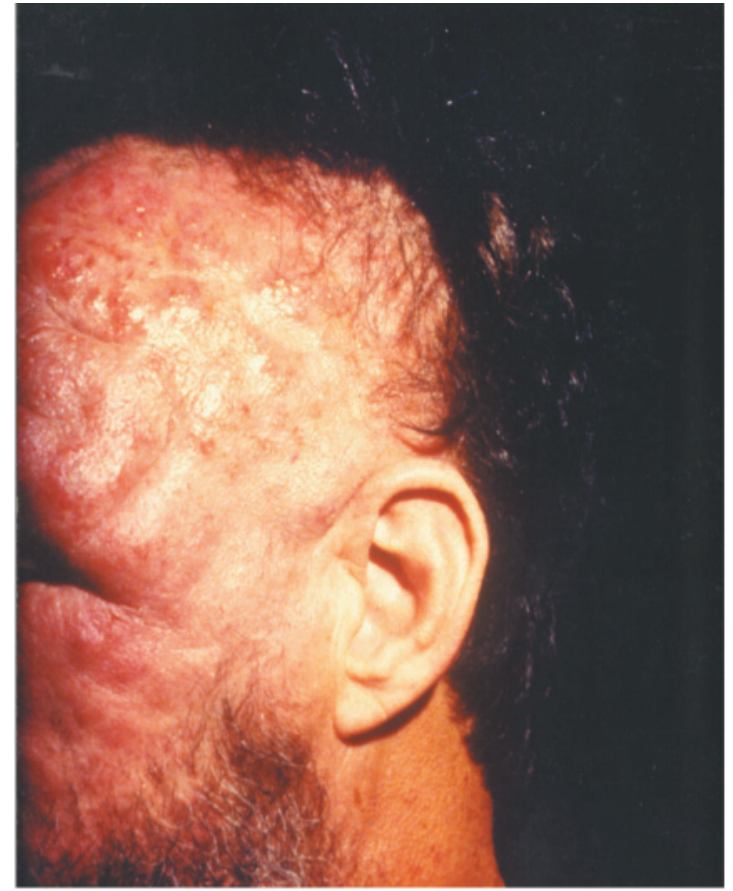

Fig. 1 - Larva migrans - left side cephalic segment with confluent, edemato-infiltrates, and cerebriform lesions.

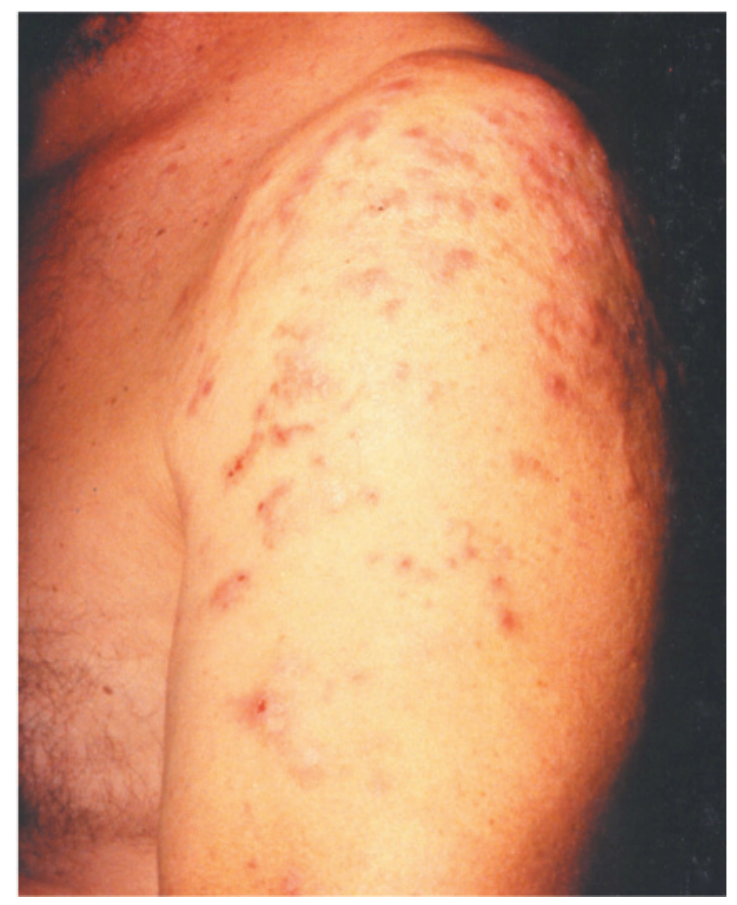

Fig. 3 - Larva migrans - left deltoidal region with erythematous and infiltrate papules, and other erythemato-serpiginous.

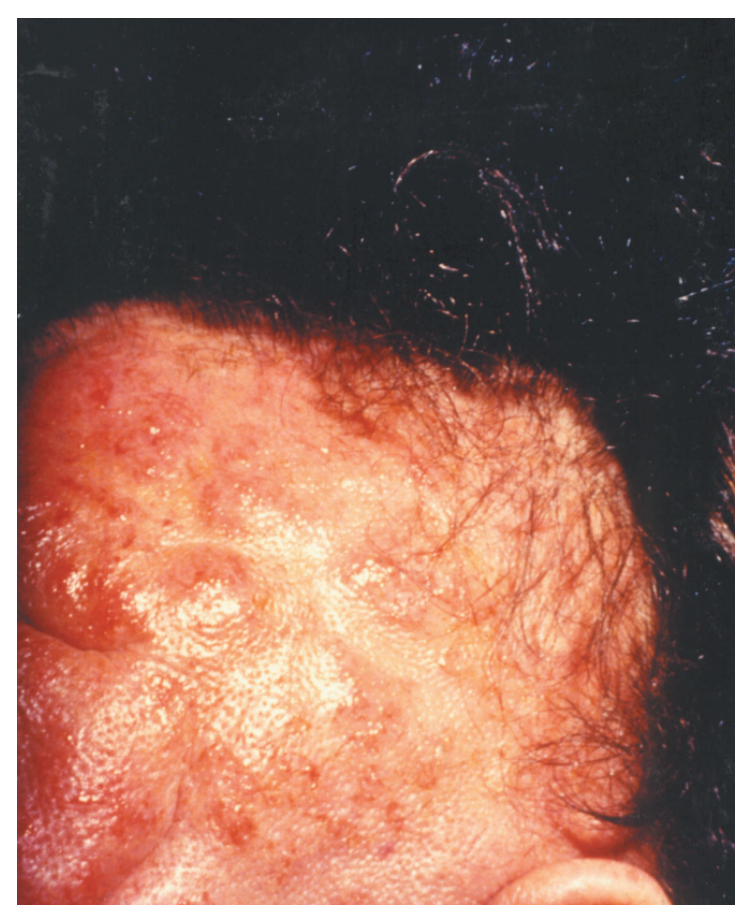

Fig. 2 - Larva migrans - close-up of the previous picture where one observes eczematoid aspects and peau d'orange of the fronto-temporal region.

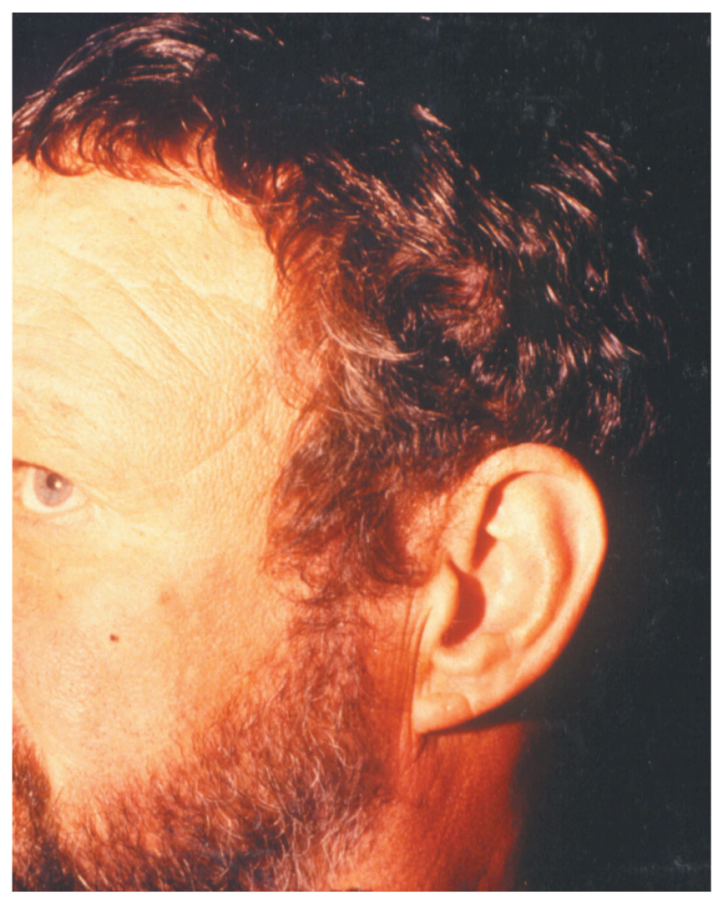

Fig. 4 - Patient after 1 month of treatment, without lesions, and with complete recovery of hair growth. 


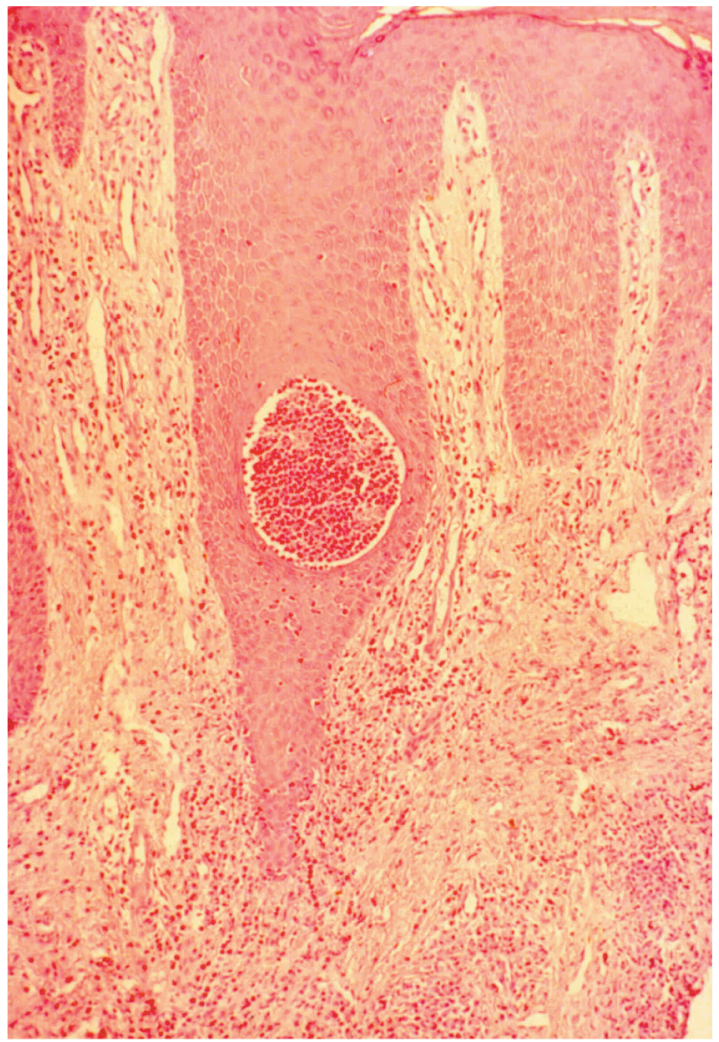

Fig. 5 - Larva migrans - a rich in eosinophils, chronic inflammatory process, with epidermic hyperplasia, fibrosis, hypervascularization, and edema in the dermis. In the center of the fragment, presence of the follicular eosinophilic abscess. (HE, original magnification x100).

through the skin, reaching the veins in the dermis of these animals. They migrate to the lungs and then the trachea, being degluted. The adult worms reproduce in the intestine and the eggs are eliminated in the faeces ${ }^{4}$.

The larvae are wrapped in a protective pellicle, permeable only by gases. Attracted by the high concentration of carbon dioxide in the skin, they lose their carapaces, releasing proteases. These enzymes will enable them to migrate through the epidermis. Some authors consider the $A$. braziliense incapable of reaching the dermis since it does not have specific collagenases ${ }^{9}$.

HOLTEZ et al. demonstrated in 1992 that the larval forms of this nemathelmintes, as well as the A. caninum, produce two enzymes responsible for the tissue invasion: the proteases and the hialuronidases ${ }^{6}$. The latter have similar characteristics to those found in mammal spermatozoids.

The hialuronidases of these invertebrates are said to facilitate the migration through the skin and detach the cells of the basal membrane of the epidermis, strongly joined by the hialuronic acid. This enzyme in the $A$. braziliense in vitro is more active than the $A$. caninum, and both of them are more active than that of other ancylostomas. Whence the ease with which these two species lead to cutaneous infestation, unlike other Ancylostoma sp. ${ }^{6}$.

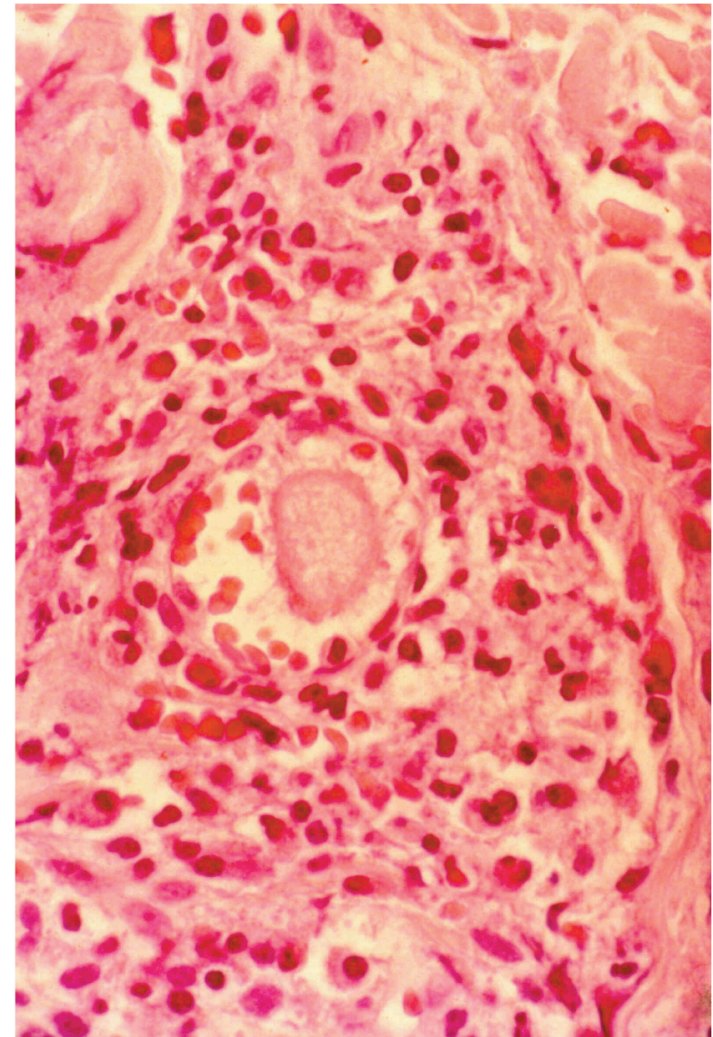

Fig. 6 - Larva migrans - small vein in the papillar dermis containing traces of larva. Exuberant peri-vascular inflammatory exudates rich in eosinophils (HE, original magnification x400).

Eosinophil-derived major basic protein and eosinophil cationic protein are the main means by which the host overcomes the energy reserves of the larva, resulting in its incapacitation and elimination'.

The incubation period is usually short and vaguely established, one or two weeks being the estimate. Experimental studies show that the larvae penetrate the pillous follicules and the orifices of the sebaceous glands. They begin migration four days after penetration and are more active at night ${ }^{2,4,5,12}$.

The main affected areas are the dorsum and sole of the feet (uni and bilateral), buttocks, pelvic waist, legs and shoulders. More than one lesion is compatible with more than one entry point ${ }^{4}$.

The main signs and symptoms are linear and/or serpiginous lesions (which progress from $2-3 \mathrm{~mm}$ to $2-3 \mathrm{~cm}$ per day) and the pruritus. This is intensified after some days by the inflammatory reaction of the host and may even interfere with sleep. Pain may occur in papulovesicular lesions ${ }^{2,4}$.

Infestation is usually self-limited, as the larva resists for anything between two days and a few weeks, although it may occasionally persist for more than a year ${ }^{3,4}$. 
Infestation with $A$. caninum usually spreads more, with systemic manifestations, folliculitis and migration to the muscles of the region?.

The diagnosis is essentially clinical and the histological features usually contribute very little to it. Wilson evaluated 300 biopsies of larva migrans lesions in 1951 and found larval structures in only eight, as reported by MILLER et al., 1991 ${ }^{\circ}$. The latter authors describe the finding of a A. caninum structure, and eosinophilic folliculitis in a patient with a clinical diagnosis and histological confirmation. They mention only one previous description of folliculitis associated clinically with larva migrans. CAUMES et al.,1995, clinically associate follicular lesions with serpiginous dermatitis in two out of 67 patients with this diagnosis ${ }^{2}$.

The main differential diagnosis should be made with the larva currens, caused by Strongyloides stercoralis, whose lesions, linear and urticated, grow on average $10 \mathrm{~cm}$ per day ${ }^{12}$. There may also be similarities with the chronic migratory erythema of Lyme's disease ${ }^{4}$.

The main therapeutic schemes are thiabendazole, $15 \%$ cream, applied 2 to 3 times on the affected areas for 5 days. Symptoms should cease within 48 hours. Albendazole can be administered in a single dose of $400 \mathrm{mg}$ or in the same daily dose for 3 to 5 days $\mathrm{s}^{4,7,8,9}$.

Ivermectin may be administered in a single dose of $12 \mathrm{mg}$ with excellent results, according to CAUMES \& GENTILINI, 1993².

Thiabendazole, taken orally, is not recommended because it is poorly effective in comparison with the other therapeutic options, especially in a single dose $e^{1}$. One reason may be that the protective pellicle of the third stage of the larva is impermeable to thiabendazole 9 . In addition, its side effects such as nauseas, vomiting, vertigo and chronic headache also limit its use ${ }^{3}$.

JONES, 1994, described the recrudescence of lesions after 3 days of albendazole, although he still considers it the best therapeutic option. This may have happened, according to him, because of the variable absorption of the drug, or because the infestation was massive. He recommends a later evaluation of patients with this condition ${ }^{7}$.

\section{DISCUSSION}

We have related a case of larva migrans with an unusual manifestation.

With regard to symptoms, the patient mentioned pain, which occurs in only $10 \%$ of cases ${ }^{4}$. In the literature, this symptom is more associated with vesiculous lesions, and in this patient an eczematous aspect in the cephalic segment was observed.

The histological finding of rich eosinophilic infiltrate, added to the information about anamnesis, led to the diagnosis. This was confirmed by finding the larval structure after exhaustive search. Besides identifying the keratin structure inside the blood vessel, which shows larva invasion, the anatomopathological exam showed various areas of folliculites with rich infiltration of eosinophils, as in the case described by MILLER et al., $1991^{9}$.

Clinical and histological finding of folliculitis and the linking of larval structure to histology, as in this case, are described in the literature as rare and more usually associated with $A$. caninum.

Repetition of treatment with albendazole is supported by the case of recrudescence already $\operatorname{cited}^{7}$, and by the fact that this was a case of massive infestation. Therapeutic success was confirmed by reevaluation after a prolonged period of treatment.

It is thought that prolonged contact of the broad affected areas with the sun may have allowed entry of multiple larvae. The presence of many spots of folliculites may be due to larval penetration through orifices of the pillo-sebaceous apparatus, as suggested by experimental studies already mentioned and observed by GUIMARÃES et al., $1999^{5}$.

The clinical exuberance may have been aided by transitory immunodeficiency caused by corticosteroid. This diminishes the cutaneous inflammatory response in many ways, such as the inhibition of phospholipase $\mathrm{A}_{2}$, of the action of cytokines, of the expression of ELAM-1 and ICAM-1, and of the liberation of histamine. In this way, it becomes efficient in suppression of the eosinophilic activity and may have increased susceptibility to this infestation ${ }^{11}$.

\section{RESUMO}

\section{Larva migrans: relato de caso e revisão}

É apresentado um caso de infestação maciça por Ancylostoma sp. em paciente que recebeu terapia sistêmica com corticosteroide. O que chama a atenção neste caso é a exuberância e a raridade da manifestação clínica. Com base na literatura pertinente, discutimos os mecanismos da infecção parasitária, a história natural da doença e seu tratamento.

\section{REFERENCES}

1. CAUMES, E.; CARRIÈRE, J.; DATRY, A. et al. - A randomized trial of ivermectin versus albendazole for the treatment of cutaneous larva migrans. Amer. J. trop. Med. Hyg., 49: 641-644, 1993.

2. CAUMES, E.; CARRIÈRE, J.; GUERMONPREZ, G. et al. - Dermatoses associated with travel to tropical countries: a prospective study of the diagnosis and management of 269 patients presenting to a tropical disease unit. Clin. infect. Dis., 20: 542-548, 1995 .

3. CAUMES, E. \& GENTILINI, M. - Traitement de la larva migrans cutanée ankylostomienne. Ann. Derm. Vénéreol., 120: 571-573, 1993.

4. DAVIES, H.D.; SAKULS, P. \& KEYSTONE, J.S. - Creeping eruption. A review of clinical presentation and management of 60 cases presenting to a tropical disease unit. Arch. Derm., 129: 588-591, 1993.

5. GUIMARÃES, L.C.; SILVA, J.H.; SAAD, K.; LOPES, E.R. \& MENESES, A.C.O. Larva migrans within scalp sebaceous gland. Rev. Soc. bras. Med. trop., 32: 187$189,1999$.

6. HOLTEZ, P.J.; NARASHIMAN, S.; HAGGERTY, J. et al. - Hyaluronidase from infective Ancylostoma hookworm larvae and its possible function as virulence factor in tissue invasion and in cutaneous larva migrans. Infec. Immun., 60: 1018-1023, 1992.

7. JONES, S.K. - Cutaneous larva migrans - 'recurrens'. Brit. J. Derm., 130: 546, 1994.

8. KIRTCHEN, L.W. - Case studies in international travelers. Amer. Fam. Phycn., 60: 471-474, 1999. 
9. MILLER, A.C.; WALKER, J.; JAWORSKI, R.; LAUNEY, W. \& PAVER, R. - Hookworm folliculitis. Arch. Derm., 127: 547-549, 1991.

10. NICHOLS, R. - The etiology of visceral larva migrans. II. Comparative larval morphology of Ascaris lumbricoides, Necator americanus, Strongyloides stercoralis and Ancylostoma caninum. J. Parasit., 42: 363-399, 1956.

11. SCHIMMER, P.B. \& PARKER, K.L. - Adrenocorticotropic hormone, adrenocortical steroids and their synthetic analogs; inhibitors of the synthesis and actions of adrenocortical hormones. In: HARDMAN, J.G.; GILMAN, A.G. \& LIMBIRD, L.E., ed. The pharmacological basis of therapeutics. Nashville, Goodman \& Gilman, 1996. p. 1471
12. STONE, O.J.; NEWELL, G.B. \& MULLINS, J.F. - Cutaneous strongyloidiasis: larva currens. Arch. Derm., 106: 734-736, 1972.

Received: 20 February 2003

Accepted: 19 May 2003 